\title{
Technology-Enhanced Learning in Developing Nations: A review
}

\author{
Shalni Gulati \\ University of Oxford, UK
}

\begin{abstract}
Learning 'using' technologies has become a global phenomenon. The Internet is often seen as a value-neutral tool that potentially allows individuals to overcome the constraints of traditional elitist spaces and gain unhindered access to learning. It is widely suggested that online technologies can help address issues of educational equity and social exclusion, and open up democratic and accessible educational opportunities. The national governments and nongovernmental agencies who fund educational endeavours in developing countries have advocated the use of new technologies to reduce the cost of reaching and educating large numbers of children and adults who are currently missing out on education. This paper presents an overview of the educational developments in open, distance, and technology-facilitated learning that aim to reach the educationally deprived populations of the world. It reveals the challenges encountered by children and adults in developing countries as they attempt to access available educational opportunities. The discussion questions whether, in face of these challenges, developing nations should continue to invest money, time, and effort into e-learning developments. Can technologyenhanced learning help address the poverty, literacy, social, and political problems in developing countries?
\end{abstract}

Keywords: developing countries; technology; e-learning; access; rhetoric; reality

\section{Introduction}

New communication technologies, particularly the Internet, appear to offer exciting possibilities for overcoming geographical access and cost barriers to learning. Yet it is hard to imagine that these technologies can have a positive influence on the education of children and adults who lack basic living resources and live with an underdeveloped educational infrastructure in an environment of political instability. This paper explores the advances in open and distance learning in developing nations, and questions if these advances are addressing the educational gaps. The discussion highlights the challenges created by poverty, lack of social and educational infrastructures, and cultural issues that restrict educational progress in developing countries. This paper explores the conundrum that learning technologies on one hand (i.e., print-material, radio, television, video, audio, telephone, computers, and the Internet) are seen as an answer to the limitations and rigidities of conventional education because they reach a larger number of learners (Sutaria, 1990); while on the other hand, where these technologies are being used, the 
difficulty of accessing them and the digital divide between privileged and deprived groups continues to widen the educational gap.

Although this paper refers to technology-enhanced learning developments in developing countries, it by no means assumes that all developing nations have homogenous characteristics, social problems, and issues. These countries differ in their political circumstances, the history of their educational developments, culture, language, religion, gender issues, population size, resources (Lewins \& Stuart, 1991), and the contemporary influx of technology. Each country has developed different forms of open and distance learning alternatives to meet the demand for education. Nonetheless, the key challenges all these nations face in trying to reach the masses and address issues of poverty and educational access make it worthwhile to compare and contrast their situations and strategies.

\section{Educational Gaps and Expansions in Developing Countries}

Most countries in Latin America, Middle East, Africa, Southeast Asia, and some parts of southern Europe, are designated as 'developing countries' because of their lower rank in the United Nations Development Program (UNDP) Human Development Index. Yet it is worth noting that these countries have rich histories and educational traditions. The Indian Gurukul system, the first schools in Egypt, and the first universities in Babylonia, are only a few examples of early and advanced education systems among developing nations (Saheb, 2005).

Since the spread of the industrial revolution and the end of WW II, there has been a widening gap in socio-economic systems, living standards, and educational opportunities between developing and developed countries (note that the latter include Western Europe, North America, Australia and New Zealand). In 1913, the income gap between the world's richest and poorest people was 13 to 1 (UNDP, 2000). By 1997, the income gap was 74 to 1 . In 1999, the richest 200 people in the world had a combined wealth of US $\$ 1,135$ billion, whereas the total income of the poorest half billion people in all developing countries barely exceeded 10 percent of that amount (UNDP, 2000). According to the United Nations Educational, Scientific, and Cultural Organization (UNESCO) (1993), in 1960 one in four children went to school in sub-Saharan Africa, one in two in Asia, and just over one in two in Latin America. Developing countries lacked educational infrastructures, teachers, economic structures, and technologies to support the demand for education at all levels.

After decolonisation (1940s - 1960s), developing nations' governments and associated nongovernmental agencies identified the need for educational infrastructures to address the widening gap between the educated and non-educated (Kamau, 2001). About a dozen developing countries, including Samoa, Columbia, Niger, Mexico, and El Salvador, with funds from various agencies including the United States Agency for International Development (USAID), UNESCO, and the French aid to North African countries, invested in televised primary schooling to reach their deprived populations (Perraton, 2000). In the 1960s, China introduced nine-year compulsory schooling, and started building schools in rural and urban regions supported by televised learning (CERNET, 2007). Emphasis on televised primary schooling in these countries further amplified the demand for human and material resources for primary and secondary education. Despite these open and distance learning alternatives to increase education for the masses, however, problems of infrastructure and access remain unresolved 47 years later. For instance, in Asia alone there are over 560 million adults, or 70 percent of the world's adult population, who cannot read or write including the majority of females (66\%) (Malik, Belawati \& Baggaley, 2005). 
In the 1960s and 70s, most developing countries based their decisions to expand educational opportunities on economic grounds, and began expansion at secondary and tertiary levels. This orientation was congruent with the goals of the World Bank, a funding agency with an economic focus (Perraton, 2000). In 1963, the World Bank considered funding education projects for the first time, but these were limited to vocational, technical, and some secondary education projects. Psacharopoulos (2006), who worked for the World Bank, argues that the projects they funded did not work because funding allocation was driven by solely economic motivations and therefore lacked focus. He reasons that the Bank had considerable inertia in understanding and fitting with different developing countries' needs (Psacharopoulos, 2006). Perraton (2000) substantiates Psacharopoulos' view and explains that the World Bank's loans responded to the demands of the urban elite and funded their children's vocational and higher education. Funding one child's university education was the same as funding 60 children's primary school education (Perraton, 2000). The result is that while the public expenditure per inhabitant on education in developing countries has gradually risen, educational expansion still lags behind that in developed countries (Perraton, 2000). Illiteracy rates in developing countries may have fallen between the 1960s and 1980s, yet there are still more than 900 million illiterate adults in the world (UNESCO, 1993).

Perraton (2000) explains that global economic conditions were not conducive to educational expansion in developing countries. The shortage of resources caused, in part, by the Organisation of the Petroleum Exporting Countries (OPEC) oil crises, global food shortages in the 1970s, and the falling prices of primary products in 1980s, resulted in increased debt, particularly in subSaharan African and Latin American countries. As a result of these changes, developed nations prospered and enjoyed the political and economic opportunities that widened access to resources for the less well-off. The situation in developing countries, however, was quite different. The reduction in resources and funding in developing countries meant that less was spent on training teachers and on educational resources for the poor (Perraton, 2000). Lack of resources, including a limited number of textbooks and desks or writing spaces, libraries without journals, and laboratories without equipment remain a reality today in many developing nations of the world (Perraton, 2000).

Lewins and Stuart (1991) propose that educational provisions in developing countries were limited due to their governments' failures to recognise and address the issues of access, culture, and the gender gap that affected poorer population groups. Lewins (1991) describes this as the 'educational planner's paradox.' His review of the research on innovation in education suggests that, although innovation has good intentions, too many changes often penalise those who need them most:

In many educational systems in developing countries, the losers in the change process are those clients on the margins of the existing system. Rural children and teachers in isolated, under-resourced, and neglected schools, with many unqualified teachers and little access to information, are those least prepared for the change. (Lewins 1991, p. 16)

The complexities of systems and funding compounded by local cultural issues hinder access for less privileged groups. These inequalities continue to exist despite the growth in communication and technology applications that are advocated to address the educational gaps in developing countries. For instance, in the late 1980s the vocational focus by the National Commission of Nomadic Education in Nigeria provided funding for radio programs to educate the rural nomadic Fulbe community in Nigeria (Usman, 2001). The program covered prevention of animal diseases, information on animal and crop practices, production of cheese, milk, and butter, cooking and nutrition programs, and religious programs. The funding agencies and organisers of these 
programs however failed to consider the difficulties Fulbe women experienced in gaining access to radios, which were purchased and used mostly by their husbands. Broadcast times did not easily fit around the busy lives of these women, who also had domestic obligations and financial responsibilities for the dairy products. As such, Usman's interviews with these women revealed unhelpful approaches and assumptions about equal access that were insensitive to Fulbe women's needs and reinforced the patriarchal norms that marginalize women.

The sections that follow highlight challenges people in developing countries continue to face as their governments increasingly employ technologies such as radio, television, audio, videocassettes, print material, and computers to facilitate the delivery of distance education to larger populations.

\section{Open and Distance Learning Successes and Challenges}

Since the 1990s, open and distance learning has gained increasing legitimacy, as evident in the policy statements by the main international agencies (i.e., UNESCO, European Commission, World Bank) and various national policies (Perraton, 2000). Lack of resources, including buildings, desks, books, and qualified teachers, has been a significant obstacle for open and distance learning. While the success of the UK Open University, established in1969, is cited as an example that led to the opening of over 25 open universities in developing countries (Perraton, 2000), it was the University of South Africa in 1946 that became the first to offer single-mode, distance education (Mackintosh, 2005). Arguably, the aims of distance education in developing countries are different from those of developed countries. In developed countries, moves to widen participation and lifelong learning for non-traditional learners are closely linked to the development of a strong knowledge economy. In contrast, developing countries' motives for distance learning are to provide basic and literacy education to large numbers of poor people (Zhang, 2005).

For instance, in 1968 Mexico launched Telesecundaria, televised lessons in distant classrooms in the presence of a teacher, to extend lower secondary schooling to its rural and far-flung communities. The cost analysis by Klees, McAnany, and Mayo (1975) concluded that even though Telesecundaria, schools had fewer and untrained teachers with larger classes than did conventional schools, the system was more cost efficient in supporting student achievement in subjects such as Spanish, math, and chemistry. The system achieved greater educational output as compared to traditional secondary schools (Klees \& Mayo, 1974). By 1993, the system had reached 15 percent of the lower secondary school learners. Since 1994, the model has used advanced satellite for televised broadcasts and local teachers to encourage interaction in distant classrooms (Calderoni, 2005). Perraton (2000) notes that although the costs per student have now increased as compared to conventional schools, Telesecundaria continues to provide a fruitful alternative model of schooling.

Lack of trained teachers has meant that several open learning initiatives in developing countries have focused on educating and training their unqualified teaching force. Bof (2004) describes the Brazilian Ministry of Education distance education model called Proformação, a distance teacher certification course designed to train 27,000 uncertified teachers in 15 Brazilian states. Proformação includes face-to-face sessions, workbook activities, practice evaluations, tutorial meetings, and bi-monthly tests. Following an evaluation that revealed the program's positive impact on participants' teaching practices and a significantly low dropout rate $(11.5 \%)$, Proformação has been identified as the "distance learning program for the 21st century" (Moore, 2001). It is noteworthy that the successes of Proformação and Telesecundaria are attributed to 
print and television technologies (Bof, 2004) and not the Internet, which remains inaccessible to most individuals in these countries.

Not all distance education in developing countries has been successful. Kamau (2001) describes the challenges and constraints in developing distance education for Kenyan and Botswanan untrained primary school teachers. As in Mexico, the courses use printed learning materials, supported by educational radio, occasional audiocassette tapes, and face-to-face sessions. Since 1985, course development has faced resistance from conventional university staff and procedural barriers that give priority to campus-based programs. National policy requirements and deadlines allowed limited time to complete the course material, which consequently led to high dropout rates (Kamau, 2001). The courses were developed and supported by campus-based teachers that typically lacked the requisite experience or skills in developing distance material. Additionally, the tutor-students did not have equal access to audio technologies needed for the course (Kamau, 2001).

The University of West Indies Distance Teaching Experiment in 1978 began with similar problems. Funding from USAID was used to develop real-time, interactive teaching using satellite television, regional telephone links, and teleconferencing centres in local schools and colleges supported by live audio communications, lectures, and print course materials (Marrett \& Harvey, 2001). By the late 1980s, the University of West Indies' Distance Teaching Enterprise (UWIDTE) became a significant contributor to social and medical science education. In 1996, the University of West Indies established non-campus distance education as one of its key functional departments to serve the 16 Caribbean countries. Distance education, however, was still being sidelined by face-to-face teaching faculty who viewed it as an add-on, and voicing fears they were 'giving away' their intellectual property. They did not view their distance teaching experience as a positive influence on their careers, nor did they identify with distance education's goal of widening access.

Interestingly, distance education was also perceived as 'second best' in Asian countries. This is in spite of the fact that Asia has clearly led the way in open and distance learning enrolments. In the 1970s and 1980s, when conventional Asian universities faced limited investment, enrolment in open universities throughout Asia increased from 4.9 percent in 1980 to 7.0 percent in 1990 (Perraton, 2000). The Chinese Central Radio and TV University (CERNET, 2007), established after the end of the 'Cultural Revolution' in 1976, and the Indian state (Naidu, 2005) and national open universities established in 1982, demonstrate two distinct models of distance education in Asia. Their aims were to meet the growing demands of secondary and tertiary education and to widen access to the masses.

According to Rufang (1997), the Chinese government intention was to use Chinese Radio and TV University for socialist construction much at the cost of individualism. The University aimed to produce a qualified work force and raise the social and cultural standing of the country. This coincided with the introduction of a 1985 compulsory education policy focused on nation building. The Radio and TV University alongside conventional institutions was charged with training 105 million of China's workforce, including technical and engineering personnel and 3.5 million new teachers (Rufang, 1997). Since the 1980s, personal computers have begun to change the mode of dissemination of learning materials, while radio and television enhanced by satellite transmissions remain the main methods of teaching. According to the China Education and Research Network (2001) by 1999, the Chinese Radio and TV University had seen over 2.6 million college and vocational school graduates, 35 million non-degree graduates for continuing 
education, and in-service training and tens of millions of farmers for various agricultural practices.

An insufficient infrastructure and growing demand for secondary education led India, a secular democracy, to develop an alternative model, National Open School (NOS) (Sujatha, 2002). The school offered non-formal, distance schooling for learners of all ages. Using paper-based selflearning material, the school intake increased from 1,672 enrolments in 1981 to 3,355,100 by 1999. The chance to sit for the same exams as formal schools has added to the standing of open schooling. As in China and other developing countries however, in India there are also gender gaps. Only 36 percent of those enrolled in NOS courses since 1990 are female. Furthermore, although there are low or no schooling costs for members of India's scheduled castes and tribes groups that make up a high proportion of India's population - enrolment from these groups remains the lowest, at 21.92 percent. Outcomes of the system are also questionable because the pass rate for secondary and senior secondary levels in 1999 was between 25 percent to 29 percent (Sujatha, 2002).

The above examples demonstrate the variety of open and distance learning methods that have been successfully implemented, and that have reached at least some of the poorer and deprived groups in developing countries. The following sections outline the hidden challenges faced by these countries as they join the international economic race.

\section{The Poverty Challenge in India and China}

Economists have identified India and China, the world's two most populated and diverse nations, as the fastest growing economies in the world ("New World Economy," 2005). India, as a global leader in the out-sourcing of IT services is, unlike most developing countries, contributing to the technological revolution (Sharma, 2005). The growth of China's manufacturing industry now means that most products used by people around the world are manufactured in China. The Indian and Chinese open and distance learning case studies above, combined with their economic success, paint a picture of success in education and opportunity for their people. Do all Indian and Chinese citizens share these successes?

Per capita incomes for India and China are rising, but this may be happening at the expense of the poorer citizens in these populous nations. A closer look at the critical literature on distance education exposes the poverty challenges that persist despite the economic growth and technological developments of these two nations (Carr-Chellman, 2005). According to Abdul Waheed Khan of the Indira Gandhi National Open University, (Sharma, 2005), despite the Indian NOS schools raising the aspirations of the poorer classes, "only $6.5 \%$ of school graduates pursue higher education degrees in India as compared to 30\% in developed countries" (p. 54). This highlights the educational divide in India, which dates back to the policies proposed after independence in 1947.

While NOS has reached some individuals and helped to raise their living standards by enabling them to gain employment in different government sectors, overall there has been limited funding to address the growing demands of primary education sectors. Unlike China, which made primary education compulsory in 1960s, since Independence in 1947 India has concentrated investment in university education (Sharma, 2005). As a result India now has a large number of uneducated adults (Dhanrajan 1997, cited in Sharma), and a small number of middle-class, educated adults and their children, who continue to benefit from private and public investments. These middle- 
class, white-collar workers are now leading the information technology revolution in India, making the elite wealthier whilst ignoring the needs of the non-elite (Sharma, 2005).

As India wrestles with the challenges and opportunities that distance technologies offer for education, it presents an example of a developing country whose economic progress may be ignoring the diverse educational needs of 75 to 90 million children (Human Rights Watch, 1996, cited in Badiwala, 1998). This is the estimated number of children from poor families who work in agricultural and industrial employment and contribute up to 37 percent of the total household income (Badiwala, 1998). India's child labourers are typically exploited and paid much less than adults. Badiwala concludes that a combination of poverty, caste system, parental attitudes, lack of schools, expense of schooling, and government neglect continues to fuel this oppressive situation.

The Indian Constitution (Article 24) identifies the need to protect children from forced labour, but it was not until 1994 that the government called for elimination of child labour altogether. Yet there is no evidence that this proposal is being enforced. Only recently has the Indian government sought to make free and compulsory education a fundamental right for all children between 6 and 14 years of age (UNESCO, 2004). Badiwala (1998) discusses the successes of Sri Lanka and the Indian state of Kerela, which have enforced compulsory education, and by spending more on mass primary and secondary education than on higher education. This enforced compulsory education, combined with the changing attitudes and aspirations of the people, has reduced child labour in Sri Lanka and Kerala, but the remainder of the Indian subcontinent lags behind in basic education.

The reality of rural China also challenges the rhetoric of open access and social equality of the Chinese education system (Wei, 1999 \& MOE, 2002, cited in Zhang, 2005). Despite China's television and radio distance learning being focused on providing nine-year compulsory education to rural populations, many rural poor children continue to fall short of the national goal (Hannum, 1999). The government and the World Bank have provided investment and fee waivers for basic education in poor provinces ( $\mathrm{Li} \&$ Piazza, 2002). The Chinese government has identified means to link institutions between the developed (eastern) and less developed (western) regions of China for one-to-one developmental support (Ma, 2004; Zhang, 2005). Zhang questions the long-term effectiveness of these policy-driven support initiatives to meet the needs of the 800 million rural Chinese (Li \& Piazza, 2002) in a market-driven economy.

Ma (2004), in her travels to China, found that despite these initiatives, rural schools have great difficulty attracting qualified teachers. The chances of urban school aged children going into higher education are three or four times greater than rural children (Ma, 2004). This is compounded by the trend towards reducing government spending on higher education and increasing private sector funding ( $\mathrm{Wu}, \mathrm{Li} \&$ Wong, 2005), the latter of which tends to favour developed, urban centres over poor, rural regions (Zhang, 2005). This unequal distribution of wealth and educational opportunities has meant that while the rural populations are the long-term engine behind economic development (Ma, 2004), they hardly benefit from economic progress. In a journalistic review, Wingfield-Hayes (2006) shows that rural people are treated like secondclass citizens who have lower hygiene standards and educational abilities. As Chinese cities expand, rural populations who will work for a minimal wage or no wage at all are migrating to urban centres (Qiang, 2005). The urban expansion, according to Wingfield-Hayes, is also resulting in surrounding villages being bought by developers without the knowledge of, or payment to, the impoverished villagers who own the sections of communally leased land.

There are some poorer social groups in urban areas that have benefited from vocational and occupational learning opportunities (Zhang, 2005); however, there remain limited policy 
proposals and funds planned to engage rural groups in higher academic learning. The Chinese Ministry of Education clearly distinguishes between types and forms of educational investments made available to urban and rural populaces. Wei (1999, cited in Zhang), the vice minister of the Ministry of Education, concludes that access to education in rural regions, particularly in western China, will continue to be a "one-way broadcasting" medium, but one that "costs much less," with the "average ownership of TV sets [being] ninety-two percent in 1997" (Zhang, 2005, p. 24). Such attitudes influence continuing investments in education and technology in cities and areas that already have access to IT, and not in rural regions that lack infrastructure.

Similar cyclical dilemmas of investment in educational opportunities are evident in Pakistan, which like many developing countries lacks highly educated faculty, has higher education institutions concentrated in urban areas, and remains influenced by social, cultural, and political factors that do not allow people, particularly women, to leave their homes to study in cities (Toor, 2005). For countries like Pakistan, Afghanistan, Iraq, Palestine, and countries in sub-Saharan Africa, political instability makes it even more difficult to have policies that address the education gaps between the rich and poor. While there is an assumption that lack of education and poverty can increase recruitment by militias and terrorist organisations, the available evidence by experts suggests no connection between poverty, education, and participation in terrorism (Krueger \& Malecková, 2003).

\section{Computers in Education and the Digital Divide}

What can new information and communication technologies (ICTs) do to raise the status and actual and perceived quality of distance education status in developing countries? And what can they do to influence the status of those who engage in distance learning? Can ICTs benefit those who are resource poor and have limited or no access to paper-based modes of distance education delivery? The 1990s saw an increase in developing countries' policies to introduce computers in schools, with the aim of enabling students to gain basic computer skills. The following section questions who is benefiting from this introduction of computers and how.

The 1998 Working Conference on Capacity Building for IT in Education in Developing Countries demonstrated the importance that developing countries' governments place on computer education (Marshall \& Ruohonen, 1998). The conference representatives identified the need to provide computers to enable students to first develop computer skills, and second to use computers to learn at a distance.

As an example, Botswanan policies identify computer education as necessary for the people of Botswana to compete in a modern, IT-driven, global economy (Ojo \& Awuah, 1998). Their goal is not to create computer experts, but to give citizens basic computer skills and to enable them to use computers for learning. Despite the government's efforts to supply computers to primary and secondary schools, there are significant challenges, including a shortage of teachers who know how to use computers and teach IT skills. The rural-urban infrastructure disparities indicate that while urban areas can boast about electricity and telecommunications, rural areas remain unconnected and hence disadvantaged. There is a high dependency on expatriate teachers and learning materials developed in the West to support teaching in subjects such as science and technology. Limited internal human resource capacity means learning is not specific to the local populations and their learning needs. The critical challenge in Botswana is the need to balance investment in computer education against more pressing needs of basic living resources, particularly in rural and deprived areas (Ojo \& Awuah, 1998). 
Likewise, efforts of the Namibian government to offer computer education in schools since 1995 have resulted in only the most privileged private schools connected, with 0.5 percent to 2.6 percent of students enrolled in computer courses at any one level (Kiangi, 1998). While the number of Internet cafés in urban areas is growing in Namibia, the telecommunications infrastructure and human resources to provide computer education in rural areas remains underdeveloped to meet the educational demands of the poor majority. Kiangi also points out that these challenges mean, "Namibia is mainly a consumer rather than developer of IT" (p. 46).

Similar findings were confirmed in a survey of IT used in education in the Philippines. Philippine educators have used combinations of radio, print, audio, and video recordings for distance education of learners scattered around the Filipino islands since 1952 (dela Peña-Bandalaria, 2007). Yet the country faces typical infrastructural and digital divide challenges between ruralurban populations when it comes to using computers and associated technologies for learning. The proliferation of mobile phones in developing countries like the Philippines may enhance the development of mobile learning (m-learning), to educate the masses. The University of the Philippines' Open University launched an m-learning program in 2004 that offered print and mobile materials for simple and universally relevant health, literacy, and numeracy education. Such mobile learning programs may have potential for growth, but the limited capacity of mobile devices, the cost of synchronous interactions, and the rural-urban divide may hinder further developments (dela Peña-Bandalaria, 2007).

Other developing countries that have large populations and a rural-urban divide also have less than 1 percent of their populations accessing the Internet (Mutonyi \& Norton, 2007). China, for example, has 70,000 schools with computers and more than 10 million students who have mastered basic computer skills, but most of these schools are in cities, not in poorer, rural areas (Zhang, 2005). Despite the availability of technologies in urban regions, rural and poor people continue to be deprived of investment, infrastructure, and skilled teachers. Thus far, the introduction of computers into education in developing countries seems to have done little to widen educational access to the rural poor, who also do not have easy access to conventional schools and colleges. A small percentage of individuals are gaining access to computers in developing countries; however, this minority is not yet ready to contribute independently to the world's digital content. They remain the consumers rather than producers of this content.

\section{Is E-learning Working?}

A review of 150 distance education programs in sub-Saharan Africa has concluded that traditional, paper-based means of distance learning continues to be more reliable, sustainable, and widely used than online and Web-based methods of learning (Leary \& Berge, 2006). Does this imply that developing countries with limited infrastructures should not use online learning methods? There have been reported advances in e-learning in developing countries, and there are several determinants that may influence e-learning success in these countries, as exemplified in the case studies below.

First, Internet access at home is an obvious determinant of who has access to online learning and who benefits from these e-learning initiatives. According to UNESCO (1999, as cited in Mackintosh, 2005) 42 percent of the inhabitants of developed countries have telephone connections in contrast with 4.5 percent in developing countries, and only a mere 1.4 percent in sub-Saharan Africa. In addition, most single telephone connections in rural areas in developing countries are typically shared among communities, rather than owned by individual households (Mackintosh, 2005). The cost of Internet connections remains high for those who cannot afford 
such basic educational necessities. For instance, in Turkey, a middle-income country, the cost of an Internet connection (available only in cities) is US \$50 per month, a substantial proportion of the average monthly income of between US \$300 and \$500 (Gursoy, 2005). This basic lack of infrastructure in telecommunications continues to define the online learning experience of different groups of learners in developing countries.

A survey of 387 students in their final undergraduate year at the Virtual University of Pakistan (established in 2002) concluded that the majority of students (over 90\%) found learning over the Internet and via satellite TV beneficial (Hussain, 2007). As of 2004, however, Pakistan had only five internet cafés for every 10,000 people, and most students rely on these locations for access (Syed, 2004). The result is that Pakistani students in this study reported difficulties in accessing computers, libraries, friendly learning environments, and efficient mentors. The majority also reported on electricity failures, computer vision syndrome, finger joint pain, backaches, headaches, and dizziness due to occasional long periods of computer use to compensate for limited access (Hussain, 2007).

At Indonesia's Open University, the University of Terbuka, 320,000 students reported similar limitations in online infrastructure and access (Belawati \& Zuhairi, 2007). Distance education systems and students continue to rely heavily on post, courier services, and telephones (Belawati \& Zuhairi, 2007). The widespread use of print, audiocassettes, face-to-face tutorials, and intermittent, government-controlled radio and television broadcasts supports over 600,000 urban, sub-urban, and rural learners attached to the Bangladesh Open University (Islam, Rahman \& Rahman, 2006). These traditional methods may be more reliable, but they are often one-way and lack teacher-student and student-student interactivity.

Second, the underlying intentions and goals of investment and educational developments determine whether deprived and poorer groups are able to participate in the information society. The Prime Minister of India, Atal Behari Vajpayee (1998, cited in Sharma, 2005) recognised the potential of information technology to enable the Indian citizen to "overcome historical disabilities and once again become the master of [his or her] own destiny" and to "enable India to achieve the goal of becoming a strong, prosperous and self-confident nation" (Sharma 2005, p. 56). The recent announcement by the Indian government that it will invest in providing free broadband to all residents by 2009 is ambitious and a step in the right direction ("Broadband Initiatives," 2007). India's technology and distance learning institutions, including the Indira Ghandi National Open University (IGNOU), the Indian Institute of Technology, the Birla Institute of Technology, and the School of Education Technology at Jadavpur University, have led the way in online degree courses and modules (Sharma, 2005). A government supported project called Vidyakash aimed to develop support and training for teachers and provide an infrastructure for Indian institutions to use Internet technologies for education. As a consequence, India now has 4 million technology workers, 700,000 software professionals, and 1,700 technical institutes (Sharma, 2005). These initiatives, however, have arguably been supported by courses demanding high fees and therefore remain the privilege of the elite, educated, and wealthy. Moreover, they fail to consider the need to provide basic literacy and computer skills and access to computers to poorer groups before they can begin to engage in higher online learning.

Third, there are issues surrounding the practice of buying offshore courses with the aim of meeting the learning needs of diverse population groups. The World Bank-supported African Virtual University Project is being launched in African universities to provide online access to undergraduate and remedial academic courses, including calculus, differential equations, physics, chemistry, statistics, computers, and engineering. Academics, administrators, and technologists in Western countries including Australia, United States, Canada, and Belgium have led the task 
force, seminars, and courses. For example, for mounting on the system, "Universities in Belgium and Canada are developing French-language seminars in business management, environment, teacher training, and computer and Internet literacy. Recently, a curriculum task force was formed to structure a four-year undergraduate degree program in computer science, computer engineering, and electrical engineering” (World Bank, 1998, ๆ 2). Mackintosh (2005) argues that for sub-Saharan African countries, the offshore courses provided by Western countries may result in university education becoming even more elitist. Zhang (2005) also critiques the courses available from U.S. universities in China, and argues that these courses are not culturally grounded, have language barriers, and exhibit limited awareness of students' backgrounds and experiences in the field of study.

Fourth, the types of courses and learning methods influence who has a greater opportunity to contribute to global, digital content and developments. For example, in India and China, computer-supported courses and computer skills courses available for the less privileged are focused on developing vocational skills to perform an identified task. These tasks are typically repetitive and often require working for long hours for a sub-contract firm, which, in turn, is contracted by larger software companies or service providers. This is in contrast with the computer education programs developed by collaboration between the government and foreign investors to train software engineers (Sharma, 2005). Entry into the latter programs is extremely competitive and targeted at upper middle-class professionals, who gain the opportunity to contribute to the digital content. In the information society, this division between which computer courses are available to whom further contributes to the digital divide and widens inequalities between 'haves' and 'have nots.'

The above discussion of e-learning determinants suggest that e-learning does have the potential to meet the educational needs of masses of poor people in developing countries; however, this potential has yet to be recognised. The present IT provisions in developing countries is limited to the elite. Existing infrastructures allow only a few to develop communication and interaction skills and to become part of the new social networking paradigm. Education for the masses continues to be didactic and devoid of interaction and critique. And while e-learning may offer the opportunity to shift the distance learning paradigm from delivery of content towards learnercentred and discussion-led learning, continuing reliance on print material and broadcast technologies dominates in developing countries (Islam, Rahman \& Rahman, 2006). The IT access gap is contributing to the widening digital divide between haves and haves not in developing countries.

Developing countries, wherein only a small proportion of the population has Internet access, need to realise the disparities between rural and urban communities, male and female students, and elite and non-elite groups. They need to consider how to adapt global software and hardware to benefit all of their citizens. Distance learning quality frameworks need to take into account the actual needs of their target populations, not just the learning content (Belawati \& Zuhairi, 2007). Belawati (2005) identifies this as the critical challenge for developing countries - to educate students and teachers to use computers and develop accessible infrastructures so that they may benefit from the interactivity offered by online learning.

\section{Conclusion}

This paper provides an insight into the challenges faced by policy makers, educational institutions, course developers, and learners dealing with issues of access to education in developing countries. The analysis of open and distance learning developments in developing 
countries concludes that although these developments aim for equitable and extended educational opportunities that extend to disadvantaged and poor populations, the lack of educational and technology infrastructures, lack of trained teachers, negative attitudes towards distance learning, social and cultural restrictions imposed on girls and women, and inappropriate policy and funding decisions, have all resulted in furthering the gap between the rich and poor, rural and urban, and between genders.

The paper has identified significant challenges developing countries face when attempting to make learning more accessible by using Internet technologies for poorer populations. The literature shows that while distance learning and e-learning are advocated as easily accessible, for the rural poor in the developing world, books, teachers, classrooms, money, and time, continue to be significant issues. The availability of new technologies may have opened up developing economies to the world market, but they have done little to help deprived groups gain access to educational opportunities. There remain high percentages of people from lower social classes, females, and rural areas, who continue to be marginalized due to their lack of access to adequate learning resources and basic education.

This paper concludes that in many cases where there is limited IT infrastructure, traditional technologies such as printed material, radio, and television remain more effective and accessible for rural and disadvantaged groups. This conclusion, however, does not attempt to suggest that developing countries should stop developing IT infrastructures in rural and deprived areas. The implication is quite the opposite. Existing attempts to improve IT access in developing countries have promoted opportunities for some and not for others. The discussion has shown that in different developing countries it is the rich, upper middle classes and the urban elite who benefit from new infrastructures and investment. The paper recommends the need for holistic policies that acknowledge these challenges and focus on basic and primary educational infrastructure to support low-cost, higher quality access in rural and deprived areas. This is important not only for equal access to learning, but also so that different groups may have the opportunity to contribute to the development of global knowledge.

\section{References}

Badiwala, M. (1998). Child Labour in India: Causes, governmental policies and the role of education. The Child Labour Inquiry, 1. Retrieved June 7, 2007 from: http://www.geocities.com/CollegePark/Library/9175/inquiry1.htm

Belawati, T. (2005). The impact of online tutorials on course completion rates and student achievement. Learning, Media and Technology, 30(1), 15-25.

Belawati, T., \& Zuhairi, A. (2007). The Practice of a Quality Assurance System in Open and Distance Learning: A case study at Universitas Terbuka Indonesia (The Indonesia Open University). International Review of Research in Open and Distance Learning, 8(1). Retrieved June 1, 2007 from: http://www.irrodl.org/index.php/irrodl/article/view/340/774

Bof, A. M. (2004). Distance learning for teaching training in Brazil. International Review of Research in Open and Distance Learning, 5(1). Retrieved June 1, 2007 from: http://www.irrodl.org/index.php/irrodl/article/view/172/387

Broadband Initiatives: Speed it up. The Economic Times. (2007, April 27). Retrieved June 1, 2007 from: 
Technology-Enhanced Learning in Developing Nations: A review Gulati

http://economictimes.indiatimes.com/Opinion/Editorial/Broadband_initiatives_Speed_it_ up/articleshow/1962328.cms

Burge, E. J., \& Haughey, M. (Eds.). (2001). Using Learning Technologies: International perspectives on practice. London: RoutledgeFalmer.

Calderoni, J. (2005). Telesecundaria: Using TV to bring education to rural Mexico. Education and Technology Technical Notes Series, 3(2). Retrieved June 1, 2007 from: http://wbln0018.worldbank.org/HDNet/HDdocs.nsf/C11FBFF6C1B77F9985256686006 DC949/1635F1703FE053B385256754006D8C3F/\$FILE/telesecundaria.pdf

Carr-Chellman, A. A. (Ed.). (2005). Global Perspectives on E-learning: Rhetoric and reality. London: Sage Publications.

CERNET. (2007). CERNET: China's education and research network. Retrieved June 1, 2007 from: http://www.edu.cn/english_1369/index.shtml

China Education and Research Network (2001). China Central Radio and TV University (III) Talent Training. Retrieved February 12, 2008 from: http://www.edu.cn/ccrtv_1459/20060323/t20060323_3925.shtml

dela Peña-Bandalaria, M. (2007). Impact of ICTs on open and distance learning in a developing country setting: the Philippine experience. International Review of Research in Open and Distance Learning, 8(1). Retrieved June 1, 2007 from: http://www.irrodl.org/index.php/irrodl/article/view/334/792

Gursoy, H. (2005). A critical look at distance education in Turkey. In A. A. Carr-Chellman (Ed.), Global Perspectives on E-learning: Rhetoric and reality (pp. 115-126). London: Sage Publications.

Hannum, E. (1999). Political change and the urban-rural gap in education in China, 1949-1990. Comparative Education Review, 43(2), 193-211.

Hussain, I. (2007). A study of student's attitude towards virtual education in Pakistan. Turkish Journal of Distance Learning, 8(2). Retrieved June 1, 2007 from: http://tojde.anadolu.edu.tr/

Islam, M. T, Rahman, M. M., \& Rahman, K. M. R. (2006). Quality and processes of Bangladesh Open University course material development. Turkish Journal of Distance Learning, 7(2). Retrieved June 1, 2007 from: http://tojde.anadolu.edu.tr/

Kamau, J. W. (2001). Developing Course Materials: A context of technology constraints. In E. J. Burge \& M. Haughey (Eds.) Using Learning Technologies: International perspectives on practice (pp. 48-60). London: RoutledgeFalmer.

Kiangi, G. (1998). Computer education and human capacity for information technology in Namibia. In G. Marshall \& M. Ruohonen (Eds.), Capacity building for IT in education in developing countries (pp. 39-48). London: Chapman \& Hall.

Klees, S. McAnany, E., \& Mayo, J. (1975). The Mexican Telesecundaria: A cost-effective analysis. Instructional Science, 4(3/4), 193-236. 
Klees, S., \& Mayo, J. (1974). Extending the School with Television: The case of Mexico’s Telesecundaria. Paper presented at the American Educational Research Association Meeting, April 7, Chicago, Illinois.

Krueger, A. B., \& Malecková, J. (2003). Education, Poverty and Terrorism: Is there a causal connection? Journal of Economic Perspectives, 17(4), 119-144. Retrieved August 4, 2007 from: http://www.krueger.princeton.edu/terrorism2.pdf

Leary, J., \& Berge, Z. L. (2006). Trends and challenges of e-learning in national and international agricultural development. International Journal of Education and Development using ICT, 2(2). Retrieved June 16, 2007 from: http://ijedict.dec.uwi.edu/viewarticle.php?id=179\&layout=html

Lewins, K. M. (1991). Change makers and change models. In K. M. Lewins \& J. S. Stuart (Eds.), Educational Innovation in Developing Countries (pp. 7-20). London: Macmillian.

Lewins, K. M., \& Stuart, J. S. (Eds.) (1991). Educational Innovation in Developing Countries; Case studies of change makers. London: Macmillian.

Li, G., \& Piazza, A. (2002). The Interaction of Health, Education and Employment in Western China: A research proposal. Retrieved August 4, 2007 from:

http://china.pop.upenn.edu/gscf/documents/WBnobudget.PDF

Ma, W. J. (2004). Education in Urban and Rural China: Project summary. An Avery Foundation funded travel project: Research travel-blog. Retrieved August 4, 2007 from: http://www.klab.caltech.edu/ ma/chinareport.html

Mackintosh, W. (2005). Can you lead from behind? Critical reflections on the rhetoric of elearning, open distance learning, and ICT for development in sub-Saharan Africa (SSA). In A. A. Carr-Chellman (Ed.), Global Perspectives on E-learning: Rhetoric and reality (pp. 222-240). London: Sage Publications.

Malik, N. A., Belawati, T., \& Baggaley, J. (2005). Framework of collaborative research and development on distance learning technology for Asia. Paper presented at the 19th Annual Conference, Association of Asian Open Universities, Jakarta, Indonesia. Retrieved June 9, 2007 from: http://www.pandora-asia.org/downloads/05AAOU_MalBelBag.pdf

Marrett C., \& Harvey, C. (2001). Getting the Systems Right. In E. J. Burge \& M. Haughey (Eds.). Using Learning Technologies: International perspectives on practice. London: RoutledgeFalmer.

Marshall, G., \& Ruohonen, M. (Eds.) (1998). Capacity building for IT in education in developing countries. London: Chapman \& Hall.

Moore, M. (2001). Brazil's Proformação. 20th World Conference on Open Learning and Distance Education, April 1-5, Düsseldorf, Germany.

Mutonyi, H., \& Norton, B. (2007). ICT on the Margins: Lessons from Ugandan education. Language and Education, 21(3), 264-270. 
Naidu, C. G. (2005) Funding and Costs in Open and Distance Education: A Case Study of India. In A. Hope \& P. Guiton (Eds.) Strategies for Sustainable Open and Distance Learning. Commonwealth of Learning \& RoutledgeFalmer. Retrieved February 12, 2008 from: http://www.col.org/colweb/webdav/site/myjahiasite/shared/docs/Ch8 CS-Naidu.pdf

The New World Economy: The balance of power will shift to the east as China and India evolve. (2005, August 22). Business Week. Retrieved June 1, 2007, from: http://www.businessweek.com/magazine/content/05_34/b3948401.htm

Ojo, S. \& Awuah, B. (1998). Building resource capacity for IT education and training in schools - The case of Botswana. In G. Marshall \& M. Ruohonen (Eds.), Capacity building for IT in education in developing countries (pp.27-38). London: Chapman \& Hall.

Perraton, H. D. (2000). Open and distance learning in the developing world. London: RoutledgeFalmer.

Psacharopoulos, G. (2006). World Bank Policy on Education: A personal account. International Journal of Educational Development, 26(3), 329-338.

Qiang, L. (2005, September 4). Workers pay price for China's economy. Seattle Post Intelligencer Online. Retrieved August 3, 2007 from: http://seattlepi.nwsource.com/opinion/239170_huvisitop.html

Rufang, W. (1997). Chinese Network of Radio and Television Universities and the British OU: A comparative perspective. Hagen: Zentrales Institut für Fernstudienforschung (ZIFF).

Saheb, T. (2005). ICT, education and digital divide in developing countries. Global Media Journal, 4(7). Retrieved April 17, 2007 from: http://lass.calumet.purdue.edu/cca/gmj/fa05/gmj-fa05-saheb.htm.

Sharma, P. (2005). The distance in education and online technologies in India. In A. A. CarrChellman (Ed.), Global Perspectives on E-learning: Rhetoric and reality (pp. 52-66). London: Sage Publications.

Sujatha, K. (2002). Distance Education at Secondary Level in India: The national open school. A report for the UNESCO International Institute for Educational Planning. Retrieved May 30, 2007 from: http://unesdoc.unesco.org/images/0012/001262/126210e.pdf

Sutaria, M. C. (1990). Teaching for Maximum Learning: The Philippine experience. International Review of Education, 36(2), 243-250. Retrieved August 9, 2007 from: http://www.jstor.org/view/00208566/sp060144/06x2602b/0

Syed, S.A. (2004). National ICT strategy for education sector, Pakistan. Paper presented at the 2004 UNESCO EduTec Toolkit Workshop, Bangkok, Thailand. Retrieved August 6, 2007 from: http://www2.unescobkk.org/education/ict/resources/JFIT/policy/Pakistan.ppt

Toor, S. (2005). Hybrid model for e-learning at virtual university of Pakistan. Electronic Journal of e-Learning 3(1), 67-76. Retrieved August 3, 2007 from: http://www.ejel.org/volume3/v3-i1/v3-i1-art7-toor.pdf 
United Nations Development Program. (2000). Overcoming Human Poverty: UNDP poverty report 2000. Retrieved June 9, 2007 from:

http://www.undp.org/povertyreport/chapters/chapterindex.html

UNESCO (1993). World education report. Paris.

UNESCO (2004). United Nations Educational, Scientific, and Cultural Organization (UNESCO) Education Digest: Comparing education statistics across the world. Retrieved August 3, 2007 from: http://www.ivcs.org.uk/ijrs/April2006/UNESCO\%20GLOBAL\%20EDUCATION\%20 DIGEST\%202004.pdf

Usman, L. (2001). No One Will Listen to Us: Rural Fulbe women learning by radio in Nigeria. In E. J. Burge \& M. Haughey (Eds.), Using Learning Technologies: International perspectives on practice (pp. 92-101). London: RoutledgeFalmer.

Wingfield-Hayes, R. (2006, March 7). Chinese rural millions left behind. BBC News. Retrieved August 3, 2007 from: http://news.bbc.co.uk/1/hi/world/asia-pacific/4782194.stm

World Bank Group. (1998). Knowledge for Africa: the African virtual university. World Development Report 1998/1999 Background Papers. Retrieved August 5, 2007 from: http://www.worldbank.org/wdr/wdr98/africa/bpafr9.htm

Wu, X., Li, R., \& Wong, K. L. (2005). Chinese Higher Educational Trends Analysis Study: The case of ten universities. Paper presented at the Comparative and International Education Societies’2005 Annual Conference at the University of British Columbia, Vancouver, BC. Retrieved August 4, 2007 from: http://www.edst.educ.ubc.ca/CIES/Abstracts.htm

Zhang, K. (2005). China's online education: rhetoric and realities. In A.A. Carr-Chellman (Ed.), Global Perspectives on E-learning: rhetoric and reality (pp. 21-32). London: Sage Publications.

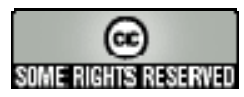

